$\underset{\text { clinical }}{\text { nephron }}$

Practice
Nephron 2017;137:297-301

DOI: 10.1159/000475607
Received: March 24, 2017

Accepted after revision: April 10, 2017

Published online: June 9, 2017

\title{
The Economic Consequences of Acute Kidney Injury
}

\author{
Samuel A. Silver ${ }^{\mathrm{a}} \mathrm{b} \quad$ Glenn M. Chertow ${ }^{\mathrm{a}}$ \\ ${ }^{a}$ Division of Nephrology, Stanford University School of Medicine, Palo Alto, CA, USA; ${ }^{b}$ Division of Nephrology, \\ University of Toronto, Toronto, ON, Canada
}

\section{Keywords}

Acute kidney injury · Costs · Economics · Hospital care

\begin{abstract}
Acute kidney injury (AKI) is an increasingly common condition associated with poor health outcomes. Combined with its rising incidence, AKI has emerged as a major public health concern with high human and financial costs. In England, the estimated inpatient costs related to AKI consume $1 \%$ of the National Health Service budget. In the United States, AKI is associated with an increase in hospitalization costs that range from $\$ 5.4$ to $\$ 24.0$ billion. The most expensive patients are those with AKI of sufficient severity to require dialysis, where cost increases relative to patients without AKI range from $\$ 11,016$ to $\$ 42,077$ per hospitalization. Even with these high costs, significant hospital-level variation still exists in the cost of AKI care. In this article, we review the economic consequences of AKI for both the general and critically ill AKI population. Our primary objective is to shed light on an opportunity for hospitals and policymakers to develop new care processes for patients with AKI that have the potential to yield substantial cost savings. By exposing the high rates of death and disability experienced by affected patients and the immense financial burden attributable to AKI, we also hope to motivate scientists and entrepreneurs to pursue a variety of innovative therapeutic strategies to combat $A K I$ in the near term.

(c) 2017 S. Karger AG, Basel
\end{abstract}

(C) 2017 S. Karger AG, Basel

\section{Introduction}

Acute kidney injury (AKI) is a common complication that affects as many as one in 5 hospitalized patients, depending on the definition employed [1-3]. In-hospital mortality for patients with AKI has recently been estimated between 20 and 25\% [3, 4], and critically ill patients with dialysis-requiring AKI experience mortality rates in excess of $50 \%[5,6]$. For patients who survive an episode of $\mathrm{AKI}$, long-term risks include chronic kidney disease (CKD) [7], end-stage renal disease (ESRD) [7], cardiovascular events [8], and reduced quality of life [9]. In one study of 415 survivors of dialysis-requiring AKI, one in 4 patients reported health-related quality of life equal to or worse than death [10].

Owing to these poor outcomes in terms of health and the patient experience, AKI has emerged as a major public health concern. The third pillar of the Institute for Healthcare Improvement Triple Aim is the cost of healthcare, with AKI-related costs likely to increase in the future as the incidence of AKI increases, with no effective thera-

Contribution from the AKI and CRRT 2017 Symposium at the 22nd International Conference on Advances in Critical Care Nephrology, Manchester Grand Hyatt, San Diego, Calif., USA, March 7-10, 2017. This symposium was supported in part by the NIDDK funded University of Alabama at Birmingham-University of California San Diego O’Brien Center for Acute Kidney Injury Research (P30 DK079337).

\section{KARGER}

E-Mail karger@karger.com

www.karger.com/nef
Dr. Glenn M. Chertow

Division of Nephrology

Stanford University School of Medicine

1070 Arastradero Road, Palo Alto, CA 94304 (USA)

E-Mail gchertow@stanford.edu 
peutic interventions currently available or in the foreseeable future [11]. This review will demonstrate the economic consequences of AKI, with the objective to stimulate new prevention and treatment strategies for this common condition.

\section{Cost Estimates in the General AKI Population}

Most cost estimates come from single center studies of academic hospitals. Chertow et al. [12] examined costs associated with in-hospital changes in serum creatinine over an 8-month period at Brigham and Women's Hospital. Relative to no AKI, the additional costs attributed to in-hospital AKI ranged from $\$ 7,469$ for a greater than $25 \%$ change in serum creatinine to $\$ 33,161$ for a greater than $177 \mu \mathrm{mol} / \mathrm{L}$ change in serum creatinine (in 1998 USD). When adjusted for age, sex, admission diagnosis, severity of illness, and CKD, the same definitions of AKI were associated with $\$ 3,721$ and $\$ 22,023$ excess hospital costs, respectively. A study at the same academic center conducted 10 years later found similar results [2]. Defining AKI using Kidney Disease Improving Global Outcomes (KDIGO) serum creatinine criteria, AKI was associated with a $\$ 7,082$ increase in costs. Estimates ranged from $\$ 5,400$ for KDIGO stage 1 to $\$ 27,300$ for KDIGO stage 3 , with similar multivariable adjustment as Chertow et al. [12].

Other cost estimates that used serum creatinine criteria to define AKI have been limited to specialized patient populations. In surgical patients at the University of Florida, the risk-adjusted average cost of care for patients undergoing surgery was $\$ 26,700$ without AKI and \$42,600 with any AKI. Patients with RIFLE-R AKI had an additional cost of $\$ 10,700$, those with RIFLE-I AKI had an additional cost of $\$ 21,400$, and patients with RIFLE-F AKI had an additional cost of $\$ 38,200$ compared with patients with no AKI [13]. Similar results were observed in a University of Pittsburgh cohort of cardiac surgery patients. Relative to age- and APACHE III-matched controls, patients with RIFLE-R AKI yielded an additional cost of $\$ 11,234$, those with RIFLE-I AKI yielded an additional cost of $\$ 20,461$, and patients with RIFLE-F AKI yielded an additional cost of $\$ 34,155$ [14].

A limitation of these studies is that medical care in academic centers tends to be more expensive than the same care in community hospitals [15]. Kerr et al. [16] used routine national data for the National Health Service (NHS) in England to estimate the cost of AKI-related care throughout the entire country. After multiple sensitivity analyses for the prevalence of AKI, the estimated inpatient costs related to AKI ranged from $£ 894,193,943$ ( $\$ 1.4$ billion USD) to $£ 1,153,732,733$ ( $\$ 1.8$ billion USD), or approximately $£ 1,100$ ( $\$ 1,700$ USD) per episode of AKI. This amount was just over $1 \%$ of the NHS budget in 2010 2011. Lower estimates outside of academic centers were also found in a study of 23 Massachusetts hospitals, where patients with complicated AKI (AKI requiring mechanical ventilation or an intensive care unit) were excluded [17]. Patients with AKI incurred median direct hospital costs of $\$ 2,600$, which still exceeded costs for asthma $(\$ 1,400)$, gastrointestinal bleed $(\$ 2,100)$, pneumonia $(\$ 2,100)$, and heart failure $(\$ 2,200)$. Non-academic hospitals incurred $17 \%$ lower AKI-related costs compared to academic hospitals.

To determine costs related to AKI in a representative population across the United States, Silver et al. [18] used data from the National Inpatient Sample, which contains administrative data for over 7 million hospitalizations from $95 \%$ of the United States population. AKI was associated with an increase in hospitalization costs of $\$ 7,933$, which decreased to $\$ 1,795$ when adjusted for patient and hospital characteristics. Compared to other acute medical conditions, adjusted mean increases in the cost of a hospitalization for AKI were similar to hospitalizations for stroke, acute pancreatitis, and pneumonia. Important variation existed in hospital determinants of cost. Nonacademic hospitals incurred $16 \%$ lower AKI-related costs compared to academic hospitals, small hospitals incurred 9\% lower costs than large hospitals, and the West census region incurred $31 \%$ lower costs than the South census region. Similar to the other multicenter studies above, Silver et al. [18] used ICD-9 codes to ascertain AKI, which identify patients with moderate to severe AKI rather than those with mild AKI [19]. Despite not fully accounting for mild AKI, the estimated inpatient costs related to AKI in the United States still ranged from $\$ 5.4$ to $\$ 24.0$ billion.

\section{Cost Estimates in Patients with Dialysis-Requiring AKI}

The most expensive patients are those with AKI of sufficient severity to require dialysis. Fischer et al. [17] found that dialysis increased costs by $63 \%$, and Silver et al. [18] showed that the additional costs attributed to dialysis-requiring AKI ranged from $\$ 11,016$ to $\$ 42,077$. These costs suggest that a small percentage of patients with AKI account for $20-25 \%$ of the incremental AKI-related hospital costs. 
Table 1. Studies evaluating the costs associated with AKI

\begin{tabular}{|c|c|c|c|c|}
\hline $\begin{array}{l}\text { Hamel } \\
\text { et al. [22] }\end{array}$ & USA, 1989-1994 & $\begin{array}{l}5 \text { academic hospitals, } \\
\text { critically ill patients }\end{array}$ & $\begin{array}{l}\text { Serum creatinine, } \\
\text { dialysis-requiring }\end{array}$ & $\begin{array}{l}\text { Median in-hospital costs = USD 31,991 } \\
\text { Cost-effectiveness = USD 128,200/QALY saved }\end{array}$ \\
\hline $\begin{array}{l}\text { Chertow } \\
\text { et al. [12] }\end{array}$ & USA, 1997/1998 & $\begin{array}{l}\text { Single center, } \\
\text { academic }\end{array}$ & Serum creatinine & $\begin{array}{l}\text { Mean adjusted increase in cost: } \\
\text { KDIGO } 1=\text { USD } 5,510 \\
\text { KDIGO } 2=\text { USD } 8,999\end{array}$ \\
\hline $\begin{array}{l}\text { Fischer } \\
\text { et al. [17] }\end{array}$ & USA, 1999/2000 & $\begin{array}{l}23 \text { Massachusetts } \\
\text { hospitals }\end{array}$ & $\begin{array}{l}\text { ICD-9 codes, excluding } \\
\text { patients requiring } \\
\text { mechanical ventilation } \\
\text { or intensive care }\end{array}$ & $\begin{array}{l}\text { Median costs: } \\
\text { All AKI = USD 2,600 } \\
\text { Dialysis = USD 4,300 }\end{array}$ \\
\hline $\begin{array}{l}\text { Laukkanen } \\
\text { et al. [23] }\end{array}$ & Finland, 2000-2002 & $\begin{array}{l}\text { Single center, } \\
\text { academic, critically } \\
\text { ill patients }\end{array}$ & $\begin{array}{l}\text { Serum creatinine, } \\
\text { dialysis-requiring }\end{array}$ & $\begin{array}{l}\text { Median in-hospital costs = USD 28,527 } \\
\text { Cost-effectiveness }=\text { USD 271,116/QALY saved }\end{array}$ \\
\hline $\begin{array}{l}\text { Hobson } \\
\text { et al. [13] }\end{array}$ & USA, 2000-2010 & $\begin{array}{l}\text { Single center, } \\
\text { academic, } \\
\text { postoperative patients }\end{array}$ & Serum creatinine & $\begin{array}{l}\text { Mean adjusted increase in cost: } \\
\text { RIFLE- } \mathrm{R}=\text { USD } 10,700 \\
\text { RIFLE- }=\text { USD } 21,400 \\
\text { RIFLE-F = USD 38,200 }\end{array}$ \\
\hline $\begin{array}{l}\text { Zeng et al. } \\
\text { [2] }\end{array}$ & USA, 2010 & $\begin{array}{l}\text { Single center, } \\
\text { academic }\end{array}$ & Serum creatinine & $\begin{array}{l}\text { Median adjusted increase in cost: } \\
\text { KDIGO } 1=\text { USD } 5,400 \\
\text { KDIGO } 2=\text { USD } 15,200 \\
\text { KDIGO } 3=\text { USD } 27,300\end{array}$ \\
\hline
\end{tabular}

ICD, International Classification of Diseases; KDIGO, Kidney Disease Improving Global Outcomes; QALY, quality-adjusted life-year.

Many of these high cost patients are critically ill. The critical care literature has largely focused on cost differences between intermittent hemodialysis and continuous renal replacement therapy (CRRT), which is approximately a few hundred dollars per day more expensive with CRRT [20,21]. Regardless of the modality selected, multiple studies have demonstrated that the provision of dialysis in critically ill patients adds between $\$ 28,000$ and $\$ 56,035$ with variation related to acute dialysis practice patterns between centers [21-23].
More important than modality selection is the costeffectiveness of providing any type of dialysis for critically ill patients. In the SUPPORT study, Hamel et al. [22] followed 490 patients in whom dialysis was initiated. The estimated cost per quality-adjusted life-year (QALY) saved by initiating dialysis and continuing aggressive care rather than withholding dialysis and allowing death to occur was $\$ 128,200$. Cost-effectiveness varied by estimated survival probability; patients in the worst prognostic category ( $\leq 10 \%$ survival) had a cost 
per QALY saved of $\$ 274,100$, and patients in the best prognostic category (41-60\% survival) had a cost per QALY saved of $\$ 61,900$. Laukkanen et al. [23] added a societal perspective (e.g., long-term disability costs) to their cost-effectiveness analysis in 410 patients with dialysis-requiring AKI. Overall, cost per QALY saved was poor $(\$ 271,116)$. Cost-effectiveness decreased with increasing age, exceeding $\$ 750,000$ per QALY for patients over 65 years of age. However, cost effectiveness approached the commonly cited threshold of $\$ 50,000$ per QALY for patients who survived for more than a year and did not require chronic dialysis $(\$ 37,172)$. These results suggest that dialysis in critically ill patients may be cost-effective under certain circumstances, but depends on recovery of kidney function and post-discharge survival, which are difficult outcomes for clinicians to predict a priori.

Few studies outside of the intensive care unit have accounted for CKD, ESRD, and other long-term outcomes in their cost analyses. Kerr et al. [16] constructed a Markov model to estimate long-term costs arising from CKD and ESRD in patients who have had AKI relative to a matched group without AKI. They found that post-discharge care for patients with AKI cost the NHS an additional $£ 179$ million ( $\$ 277$ million USD) relative to matched controls, but their estimate was very sensitive to small changes in the incidence of long-term (maintenance) dialysis therapy. More research is needed to better quantify the costs associated with post-discharge AKI care.

\section{Conclusions}

Several studies now indicate that $\mathrm{AKI}$ is expensive and consumes considerable healthcare resources (Table 1). While it is difficult to fully determine which downstream costs are attributable to AKI rather than a coexisting diagnosis, even the most conservative estimates still attribute approximately $\$ 1,700$ in excess costs for each epi- sode of AKI and $\$ 11,000$ in excess costs for each episode of dialysis-requiring AKI. In the United States, at least \$5 billion in hospital costs are related to AKI, and the true costs are likely much, much higher. These estimates only account for the inpatient costs of AKI, and ignore AKI that occurs in a primary care setting and the long-term consequences of an AKI episode. Further work is also needed to better understand hospital-level differences in AKI care and patient experiences that influence the decision to initiate renal replacement therapy.

Despite the economic and health consequences of AKI, there have been very few innovations in the prevention and management of AKI over the last decade. In the United Kingdom, a report by the National Confidential Enquiry into Patient Outcome and Death found that $30 \%$ of AKI cases were avoidable and only $50 \%$ of patients received good care [24]. Small improvements in these numbers could yield substantial cost-savings, which is one of the goals of the NHS Think Kidneys quality improvement program [25]. Similar commitment is required in other jurisdictions to help improve patient outcomes and the patient experience at a reasonable cost for the ever increasing number of patients with AKI.

\section{Acknowledgemnts}

S.A.S. is supported by a Kidney Research Scientist Core Education and National Training Program Post-Doctoral Fellowship (co-funded by the Kidney Foundation of Canada, Canadian Society of Nephrology, and Canadian Institutes of Health Research). G.M.C. is supported by a K24 mid-career mentoring award from NIDDK (K24 DK085446). Both authors approved the final version of the submitted manuscript. We certify that neither this manuscript nor one with substantially similar content has been published or is being considered for publication elsewhere.

\section{Disclosure Statement}

The authors declare no conflicts of interest.

\section{References}

1 Waikar SS, Liu KD, Chertow GM: Diagnosis, epidemiology and outcomes of acute kidney injury. Clin J Am Soc Nephrol 2008;3:844861.

2 Zeng X, McMahon GM, Brunelli SM, Bates DW, Waikar SS: Incidence, outcomes, and comparisons across definitions of AKI in hospitalized individuals. Clin J Am Soc Nephrol 2014;9:12-20.
3 Susantitaphong P, Cruz DN, Cerda J, Abulfaraj M, Alqahtani F, Koulouridis I, Jaber BL: World incidence of AKI: a meta-analysis. Clin J Am Soc Nephrol 2013;8:1482-1493.

4 Selby NM, Kolhe NV, McIntyre CW, Monaghan J, Lawson N, Elliott D, Packington R, Fluck RJ: Defining the cause of death in hospitalised patients with acute kidney injury. PLoS One 2012;7:e48580.
5 VA/NIH Acute Renal Failure Trial Network Palevsky PM, Zhang JH, O’Connor TZ, Chertow GM, CrowleyST, Choudhury D, Finkel K, Kellum JA, Paganini E, Schein RM, Smith MW, Swanson KM, Thompson BT, Vijayan A, Watnick S, Star RA, Peduzzi P: Intensity of renal support in critically ill patients with acute kidney injury. N Engl J Med 2008;359: 7-20. 
6 Uchino S, Bellomo R, Morimatsu H, Morgera S, Schetz M, Tan I, Bouman C, Macedo E, Gibney N, Tolwani A, Oudemans-van Straaten H, Ronco C, Kellum JA: Continuous renal replacement therapy: a worldwide practice survey. The beginning and ending supportive therapy for the kidney (B.E.S.T. kidney) investigators. Intensive Care Med 2007;33: 1563-1570.

7 Coca SG, Singanamala S, Parikh CR: Chronic kidney disease after acute kidney injury: a systematic review and meta-analysis. Kidney Int 2012;81:442-448.

8 Odutayo A, Wong CX, Farkouh M, Altman DG, Hopewell S, Emdin CA, Hunn BH: AKI and long-term risk for cardiovascular events and mortality. J Am Soc Nephrol 2017;28: 377-387.

9 Villeneuve PM, Clark EG, Sikora L, Sood MM, Bagshaw SM: Health-related quality-oflife among survivors of acute kidney injury in the intensive care unit: a systematic review. Intensive Care Med 2016;42:137-146.

10 Johansen KL, Smith MW, Unruh ML, Siroka AM, O'Connor TZ, Palevsky PM: Predictors of health utility among 60-day survivors of acute kidney injury in the Veterans Affairs/ National Institutes of Health Acute Renal Failure Trial Network Study. Clin J Am Soc Nephrol 2010;5:1366-1372.

11 Hsu RK, McCulloch CE, Dudley RA, Lo LJ, Hsu CY: Temporal changes in incidence of dialysis-requiring AKI. J Am Soc Nephrol 2013;24:37-42.

12 Chertow GM, Burdick E, Honour M, Bonventre JV, Bates DW: Acute kidney injury, mor- tality, length of stay, and costs in hospitalized patients. J Am Soc Nephrol 2005; 16:33653370.

13 Hobson C, Ozrazgat-Baslanti T, Kuxhausen A, Thottakkara P, Efron PA, Moore FA, Moldawer LL, Segal MS, Bihorac A: Cost and mortality associated with postoperative acute kidney injury. Ann Surg 2015;261:12071214.

14 Dasta JF, Kane-Gill SL, Durtschi AJ, Pathak DS, Kellum JA: Costs and outcomes of acute kidney injury (AKI) following cardiac surgery. Nephrol Dial Transplant 2008;23:19701974.

15 Ayanian JZ, Weissman JS: Teaching hospitals and quality of care: a review of the literature. Milbank Q 2002;80:569-593, v.

16 Kerr M, Bedford M, Matthews B, O’Donoghue D: The economic impact of acute kidney injury in England. Nephrol Dial Transplant 2014;29:1362-1368.

17 Fischer MJ, Brimhall BB, Lezotte DC, Glazner JE, Parikh CR: Uncomplicated acute renal failure and hospital resource utilization: a retrospective multicenter analysis. Am J Kidney Dis 2005;46:1049-1057.

18 Silver SA, Long J, Zheng Y, Chertow GM: Cost of acute kidney injury in hospitalized patients. J Hosp Med 2017;12:70-76.

19 Grams ME, Waikar SS, MacMahon B, Whelton S, Ballew SH, Coresh J: Performance and limitations of administrative data in the identification of AKI. Clin J Am Soc Nephrol 2014; 9:682-689.

20 Srisawat N, Lawsin L, Uchino S, Bellomo R, Kellum JA: Cost of acute renal replacement therapy in the intensive care unit: results from The Beginning and Ending Supportive Therapy for the Kidney (BEST Kidney) study. Crit Care 2010;14:R46.

21 Manns B, Doig CJ, Lee H, Dean S, Tonelli M, Johnson D, Donaldson C: Cost of acute renal failure requiring dialysis in the intensive care unit: clinical and resource implications of renal recovery. Crit Care Med 2003;31:449455.

22 Hamel MB, Phillips RS, Davis RB, Desbiens $\mathrm{N}$, Connors AF Jr, Teno JM, Wenger N, Lynn J, Wu AW, Fulkerson W, Tsevat J: Outcomes and cost-effectiveness of initiating dialysis and continuing aggressive care in seriously ill hospitalized adults. SUPPORT Investigators. Study to Understand Prognoses and Preferences for Outcomes and Risks of Treatments. Ann Intern Med 1997;127: 195-202.

23 Laukkanen A, Emaus L, Pettila V, Kaukonen KM: Five-year cost-utility analysis of acute renal replacement therapy: a societal perspective. Intensive Care Med 2013;39:406413.

24 Stewart J, Findlay G, Smith N, Kelly K, Mason M: Adding Insult to Injury: A Review of the Care of Patients Who Died in Hospital with a Primary Diagnosis of Acute Kidney Injury (Acute Renal Failure). A Report by the National Confidential Enquiry into Patient Outcome and Death, 2009. www.ncepod.org.uk/2009aki.htm (accessed April 4, 2016).

25 Think Kidneys. www.thinkkidneys.org (accessed November 14, 2016). 